\title{
Where Europe disappears into the sea: a trip to the old Bessarabia and the new border area of the EU
}

\begin{abstract}
This article constitutes a travelogue from a journey undertaken to the region which features in 'Borderland III'. Starting in Odessa (Ukraine), the author takes in Chișinau and Transnistria (Moldova) and Galați and Sulina (Romania), describing his experiences and observations based on the themes of 'Borderland III'. The article considers the economic redevelopment of Odessa and whether this will have a lasting effect on the rest of Ukraine; the EU aspirations of Moldova; the status of Transnistria and the contrasts between border policy between Transnistria and the rest of Moldova (where no border appears on a map), and between Romania and Moldova where crossing the border has, following independence and until Romania's accession to the EU, been a fairly relaxed process; and the lessons for the present of the Europe of diversity of the past. The author concludes that the future is uncertain but, given that the eastern end of Europe ends at the easternmost tip of Romania, an EU encompassing Ukraine must surely step beyond the usual definitions of Europe.
\end{abstract}

Keywords: Ukraine, Bessarabia, Moldova, Transnistria, Romania, border policy, economic development, EU accession, petty smuggling, security policy, Black Sea, superpowers, geo-strategic interests.

\section{Odessa}

When I land in Odessa I think I must have fallen for an advertising slogan. This is supposed to be the reincarnation of the White City on the Black Sea? The airport is dull grey; immigrants have to fill out complicated forms before being pestered by cabbies in the airport lobby.

Stepping outside, I find myself in a dreary place. An old rickety bus from the seventies is standing at a bus stop with a faded shelter; the café 'Kosmos' next to it is a blue metal shed. Nonetheless, I enter and have the young waitress, who has an unhealthy complexion, bring me something to drink. I am looking at cheap wallpaper and kitschy paintings. Stagnation in grey, desolation and boredom. Odessa shall rise again, that's what I read, but my first impression says something else.

When my travel companion from Frankfurt (Main) arrives, we decide not to go with any of the insistent cabbies but to take the public bus. Next to the driver, there is a 'magic' carpet with an oriental pattern, which looks just like a theatre prop. The passengers throw their money on it, mostly when they want to get off the bus. Beyond the misery of the suburbs with their kiosks, workshops, waste lands and prefabricated blocks of flats, old houses appear which could look quite attractive, if only they were refurbished. 
Then, a first crane arm moves over the street, and a fashionable, newly-plastered magnificent building comes into view. The traffic is getting denser; we are going at walking pace near the station, a Stalinist-classicist building. Our hotel should be nearby. We walk along the big Privoz market, where clothing and CDs, but above all vegetables and fruit, can be bought. The vendors' sun-tanned faces make it clear that the Privoz, in the immediate vicinity of the bus and train station, connects city and countryside. In the mess of stands and booths, in the crowded narrow alleys, being watched by shady characters, I suddenly understand why bazar/voksal, i.e. bazaar/station, is used as a synonym for chaos in Russian.

At the entrance to the Black Sea Novy Privoz, security officers are watching us. They consider us to be harmless - we do not have to produce any papers like that woman carrying a plastic bag in front of us - and we reach the upper floors in a lift made of pale silvery stainless steel. The reception, the room, the restaurant - all of it is like any of the places the international business community chooses to spend its nights. Only the superb kefir for breakfast shows a regional difference.

To get a good view of Odessa, it is best to walk through the city centre, which is arranged according to strict geometric principles. Strolling through the many parallel streets I am thinking about the architecture the collapsed Soviet Empire and its satrapies have left behind. Viewing the prefabricated blocks from the seventies and eighties today immediately leads to an acknowledgement of the tristesse they spread in an urban environment even if elsewhere they are more consistently assembled than here in Odessa, like the ones that can be found in East Berlin. Today, they evoke images of the implosion they once foreshadowed.

Looking at the station in Odessa with its columns and domes, or at the buildings erected in the fifties in the Stalinallee in East Berlin, which is today named after Karl Marx - whom the global financial crisis has seemingly resurrected - one can sense that they were planned for a regime of continuity. They survived the fall of their builders Ulbricht and Stalin in a better shape than did their successors made from prefabricated slabs. They imply not stagnation, nor revolution, but restoration! Resonating with the memory of past rulers, they were called 'Workers' Palaces' in East Berlin.

The airport gives the impression of a symbol of stagnation from a leaden time, but the lively city centre of Odessa is on the move. The city is no longer how Karl-Markus Gauß described it, only a few years ago, with its spacious pavements which:

Became extremely dangerous at night because the street lighting was weak even in those streets leading towards the centre, and one in two drain covers was missing.

People with mobiles are rushing through the streets, passing newly decked-out buildings as well as crumbling façades and - most prominently - construction sites and building pits, passing scaffolding and fences, where there's digging and screwing, hammering and sawing, passing under shady trees as well as crane arms hoisting struts and slabs, always accompanied by the jangling and knocking of the construction sites and the roar and the hooting of the traffic. The city will be clean and shining white once more, not least with the help of dirty cash. The biggest investor is neither the USA nor Russia, not the Ukraine nor the European Union: it is the British Virgin Islands, which 
long ago lost their virginity to organised crime. We are passing along an acacia-lined avenue named after Pushkin, who was once banned from here, towards the steps that Eisenstein made world-famous in his film The Battleship Potemkin. There's a peculiar building in the style of the Florentine Renaissance on one corner. It can't be as old as it appears - the historic city centre of Odessa was not constructed, on the instructions of Catherine II, before 1794. Entering the building we are welcomed and ushered into a hall. We attend a free public concert given by a choir and are told that the Philharmonic has been at home here for decades. However, the building was not constructed for that purpose, but as a temple for Mercury, the god of trade. Businessmen prominently erected the grain exchange here in 1898. It was here that they sold the wealth of Bessarabia.

Bessarabia - a word as from One Thousand and One Nights. But that's not true. This is a rural countryside situated mainly between the rivers Prut and Dniester, which flow into the Black Sea. During the 20th century, this strip of land, which had been annexed by Russia in 1812, saw many rulers. After the First World War, it came under Romanian rule, except for a thin corridor east of the Dniester; it then passed, according to the Hitler-Stalin Pact, into the hands of the red tyrant in 1940, only to be lost again from 1941, when the Wehrmacht invaded the Soviet Union, up to 1944. Then Stalin carved up the land - and it has remained like that until the present day, even though in a different form. Some parts were incorporated into the Ukrainian Soviet Republic; others were declared the Moldavian Soviet Republic. The border to the 'Romanian brothers,' as they were officially called despite having supported the Wehrmacht with troops, was closed until 1989. Due to the collapse of the Soviet Union, one part of the old Bessarabia now belongs to Ukraine; the most industrialised area belongs to Transnistria, a state which is recognised by no-one but supported by Russia; the biggest part is Moldova. At the same time, the old Bessarabia has lain on the outer border of the EU since Romania joined the Union in 2007.

The different peoples who settled here experienced expulsion, resettlement and murder in the last century. The region was, according to the Ukrainian writer Yuri Andrukhovyc:

An earthquake-prone transition zone between various empires.

What is happening here today? When we were in the region for the first time, in the area of the Danube Delta in the autumn of 2007, we went to a place where the great stream branches into many arms and we looked over to the Ukrainian side; there was no bridge, no ferry. The next border crossing point in this impressive riverside area, which is a UNESCO World Natural Heritage Site, is dozens of kilometres away. Separate worlds.

Back to Odessa where, passing the palace-like archaeological museum and the neobaroque opera, we have reached the Potemkin Stairs. It is here that, in 1925, Sergei Eisenstein filmed the massacre committed by the Tsar's Cossacks, a tragedy for the city's inhabitants. Three murders are emphasised: a boy, hit by a bullet, is picked up by his desperate mother who calls out 'Don't shoot!' to the approaching murderers in uniform, until both are lying dead next to each other. The mother of a small child in a pushchair is also shot and, falling to the ground, inadvertently knocks the pushchair, 
which then rolls down the steps passing the wounded and the dead. The senseless killing justifies the answer that the mutinous seamen on board the Battleship Potemkin give. They direct their cannons at the city's palaces. No dead people are shown here but, for example, a richly-decorated portal is shot to pieces. To the present day, the stairs are the landmark of the city; they are impressive on their own but imagination has made them into a mythical place of the revolution.

Today, they lead into a redeveloped quarter with luxurious restaurants and bars. We also see the living counterpart of the legless beggar in Eisenstein's film. But there's no sign of growing rancour due to the outrageous social inequality - not yet.

A few days later we inspect the villas of the rich who have quite literally walled themselves in: fences that are four, five metres high are not unusual. The menu in the nearby 'fish café' shows that the exquisite wines from France to Georgia are more expensive here than in Berlin or Frankfurt (Main); there's only one cheap drink: nonalcoholic beer. The chauffeurs of the rich can certainly afford it.

On my way back, I see two reliefs: one showing a portrait of the actor and singer Vladimir Vysotsky, deceased in 1980; the other displaying, I guess, Vasily Shukshin, a film-maker and writer who died in 1974. Two artists who were known to everyone in the Soviet Union, from the intellectual to the construction worker. Due to enormous strains and an extreme lifestyle, they died of heart attacks when they were still rather young, Vysotsky at 42; Shukshin at 45.

At the tram stop nearby there are only old people whose lives reach back into the time of these two. When I see a few younger people I ask them who the reliefs show. They all know Vysotsky, whose songs are played by buskers in Odessa and elsewhere to the present day. They do not know the other name, but they keep referring to Kalina Krasnaya. That is the title of Vasily Shukshin's most famous story, which he made into a film starring himself in the leading role. Once back in Germany, a Russian friend of mine tells me that, in her circle of acquaintances, films like Kalina Krasnaya were watched by the entire family, everyone sitting in front of the TV, from grandma to grandchild. The film tells the story of a departure to an honest life that ends in tragic death. The microcosm of the local story provides a metaphor which is understood to the present day.

Angry shouting breaks into my conversation about Vysotsky and Shukshin. It is directed at a luxury car with tinted windows using the tramway track to overtake a traffic jam. I see in the furious faces: this is about more than just a traffic offence.

Time and again we come across stark contrasts. On Deribasovskaya Street, the famous shopping mile, jewellers' shops are guarded by men in uniform carrying machine pistols and keeping a watchful eye on customers. A toothless old woman in wornout clothes is obsequiously begging for alms nearby. Next to a luxury restaurant, there are people in cheap clothes with big plastic bottles queuing at a stand pipe. They do not have piped drinking water; they have to get it here. Water stoppages do still occur and a bucket of water is normal in most households.

Odessa has always been a Jewish city, too. The ancestors of the great Israeli author Amos Oz were born here. But a rift runs through the Jewish quarter as well. The part north of the station is being redeveloped and - it is a Thursday, about 8pm - services are held in the newly-refurbished and well-attended synagogues. Expensive cars are 
parked in front, guarded by heavily-armed security staff. The other part of the quarter is worn with use and crumbled; there are no restaurants here, only snack stalls.

A mother talks about her son, Alex, who earned no more than 50 dollars a month as a skilled violinist - that was normal in the nineties. Like many others, he emigrated and today he plays the violin for the Hofer Symphoniker, a concert orchestra in Germany. Today the situation is better, she says, because many rich people need musicians for their parties and receptions:

Sometimes you can make more money in one day than you'd earn in an entire month in the orchestra.

Stories of rise and fall, greed and disappointment, loyalty and treason can be sensed in all of this, stories like the ones about pre-revolutionary Odessa by Isaac Babel, who wrote his way into worldwide fame with the Red Cavalry. Apparently there is no one yet who knows how to tell such stories about the time immediately following the collapse of the Soviet Union in such a dense and direct fashion. It remains an open question if the rebirth of Odessa for businesspeople, tourists and the rich shows that the region is recovering or whether the city will remain an isle surrounded by a sea of Ukrainian poverty.

\section{Chişinau}

The bus to Chişinau, the capital of Moldova, goes through a steppe scenery which I know from Kazakhstan. But, unlike the semi-desert around Karaganda, which is also known as the 'Hunger Steppe' because so little grows there, the vast Ukrainian plains are made from fertile black earth with none of the mineral resources underneath that Kazakhstan has.

Gradually, more and more hills appear, changing the character of the countryside. Then the first prefabricated tower blocks of Chişinau appear reaching to the sky. Here we meet members of the political class: Mihai Ghimpu, President of the Liberal Party; Dumitru Diacov, President of the Democratic Party; and Vlad Cubreacov, Vice-President of the Christian Democrats. A member of the ruling Communist Party has no time for us, for reasons we do not fully understand.

How do exponents of the liberal camp assess the situation? All are agreed that Moldova should join the European Union, but they are divided over the question of whether to join NATO. Vlad Cubreacov is a passionate supporter; he wants a Europe whose eastern border runs from the Baltic states to Ukraine and Moldova.

What about Turkey?

- Turkey is out. Once Ukraine and we have joined the EU and NATO, Russia will no longer be an empire but a normal nation state.

As things are now, and here the others agree with him, the Iron Curtain has been replaced by a Golden one. And Moldova is left outside. Many young people have to 
emigrate and many old people with pensions of no more than 40 dollars have to rely on the support of their families. With a grim sense of humour, Cubreacov says:

In a way we have already joined the EU, because the money that Moldovans working there send home is twice the amount made by their fellow countrymen at home.

Moldova is small, has only few natural resources, no access to the sea and the population speaks a special Romanian dialect, and so Mihai Ghimpu says a reunification with the neighbouring EU state would be a solution to the problems. The European Union, which all parties, even the governing communists, want to join, is the seemingly clear hope which, in fact, is really not so clear.

Split-off Transnistria, which includes around $40 \%$ of Moldova's industry, is seen by everyone as a regional conflict which has international dimensions. They hope that the Russian Army, so far from its home country, will retreat. Whether they really believe it or simply say so to a foreigner because it seems opportune remains an open question. NATO has asked for a retreat at regular intervals, the last on 18 November 2008.

\section{A dream? - Reality}

I open out two current maps: one of Moldova; one of Ukraine. I want to see whether they show the border of Transnistria, which has been claiming independence for 17 years. No border can be seen on either map. Transnistria is not recognised by any other state and yet our driver Valeri brings us to a guarded border where we have to produce our passports, where forms related to customs and entry regulations wait to be filled out. A dream? No, this is real.

Beyond the border begins the empire of the Smirnov clan and the Russian Army. As we race along a road lined with trees towards Bendery, my thoughts wander off and I imagine a meticulous official who, day after day, works at a border that does not exist on any map. He sits at his checkpoint for years, for decades; and then, perhaps shortly before retirement, world history twitches yet again and the border disappears. And somewhat later his grandchildren might ask him what he did with his life. They snort with laughter over a border that never officially existed.

In the meantime, we have reached Bendery, where we have a look at the massive fortress with its dynamic history. It was built in the $16^{\text {th }}$ century as a bulwark against the Ottoman Empire, whose rulers conquered and extended it. I have read in many places that the conversions of the building illustrate the history of the region as a buffer zone between Austria, Russia and the Ottoman Empire. Today, the fortress is a Russian military base; we are followed by a patrol making clear that we may not stop to have a closer look at the hewed stone walls erected on the bank of the Dniester. In a kiosk we can buy an aerial photograph which is said to be from 2003. It shows an empty rectangular area with eight huge towers and massive walls surrounded by jagged defence lines.

In Tiraspol, the capital of Transnistria, it is still possible to meet on the corner of Lenin Street and Liebknecht Street. Unlike in Moldova, the eternal flame for the Soviet soldiers killed in the war is still burning. There is a stiff statue of Lenin in front of the 
government building, looking over to the memorials for those killed in the Great Patriotic War (1941-45), in the Afghanistan War (1979-89) and in the War of Independence (1992).

A black-haired young man named Roman asks us while we are changing some money if we are German; he doesn't have any accent. His mum works in Germany, his dad in Tiraspol, he tells us. He grew up with his mum and couldn't get a place to study psychology. Dad then sent him to a university whose degrees are not recognised anywhere. Are we dealing with a prospective psychiatrist who, by cliché, is a lunatic? The young man does not appear to be mad at all. Russian educational establishments, such as the University of Moscow, run institutions here and, once he has finished his studies, Roman will get an internationally-recognised Russian degree.

We meet Ernest Vardanian, a journalist of Armenian descent, who sees the Transnistrian situation primarily as a conflict between elites and in the international world of politics. In his view, and unlike in Kosovo, there is no resentment between the different ethnic groups.

Tens of thousands take the bus in either direction to visit relatives, for shopping or to carry out business. Little will change as long as NATO refuses to guarantee not to expand into the region once the Russian troops are withdrawn. Look at the disappointment after 1991. None of the promises given to Gorbachev were kept. Despite all declarations to the contrary, NATO was enlarged.

Ernest is not someone who simply repeats an official opinion. His view on the Transnistrian 'elite' in power is a critical one; he describes them as thieves without a national idea. It is astonishing how openly he talks with his German colleagues. Private companies, many of which belong to the family of President Smirnov, whose picture hangs in every office, do not have to pay taxes.

We are not a second Switzerland, as promised, but rather central Africa.

It is ironic that the biggest group of companies, which owns dozens of filling stations, supermarkets and even a football team with the biggest and most modern stadium in the region, is called 'Sheriff.' The Polish writer Andrzej Stasiuk was right when he wrote:

An old apparatchik dresses up like a sheriff and hits the jackpot.

Those who want to enter a Sheriff supermarket must leave their bags in a cloakroom, just like in a theatre. The sales assistants in this clean and orderly world of commodities wear blue suits, red blouses, white aprons and caps with a blue and red trim.

Valeri talks to one of the border guards on our entry and I hear the word voda (water). I think of vodka, which is a diminutive of voda, and so ask Valeri which vodka to buy. He recommends a brand for me, but we do not have to bring any for the guards. When he buys a large bottle of water shortly before the border I think nothing of it at first, 
not until Valeri gives the bottle to the border guard, who then lets us pass without any inspection. It is disturbing, but apparently not unusual, that soldiers are lacking such basic things in a Russian Empire which is gaining strength once more.

\section{To Galați}

The sun is scorching on the bus as it bounces and snakes its way along the streets, which are full of potholes. We pass grey housing estates that look like camps although the impression is contrasted by colourful houses; we pass newly-refurbished church towers and brownish culture palaces worn with use. Depictions of Jesus have replaced the Lenin statues.

Exhausted, we get off the bus in Giurgiulesti, the southern-most conglomeration of buildings in Moldova. The country's only port on the Danube is being built here. Before crossing the outer border of the EU, we take some refreshment in a small restaurant while watching the border traffic. Someone offers to take us over to the other side for $€ 50$. The Romanian city of Galați is only a few kilometres away and we decline. Cars have to wait for a while and are then let through in one line; a lorry belonging to the Turkish company $\ddot{O} z \ddot{U} m i t$, which deals in fruit and vegetables, can pass through. The waitress tells us that there is no public transport. We will have to pay a driver or try to hitch a lift. When ten, twelve cars are waiting to be let through we try our luck.

A family - the son is driving - asks us in. We suspect they want to make a few euros extra for transporting us - but everything turns out quite differently.

Only a few years ago, the border crossing-point between Moldova and Romania was rather tranquil, until Romania joined the European Union. Following 1 January 2007, a new, large checkpoint has been established: up to twelve cars can be cleared at once but 25 cars wind their way into only one of the bottlenecks. One more is opened for lorries.

Here, we are surprised to see the $\ddot{O} z \ddot{U} m i t$ lorry again, which had appeared to have been let through just a moment ago. It takes an hour under the attention of the Romanian border guards until it can finally pass.

I am noting down the number of crossing-points when one of the guards snatches away my notebook. I make a protest and show my press ID. They want to get rid of us - that's why we may go ahead, passing the line of vehicles which still have to be cleared through, and we are inspected by the head of the checkpoint personally. It is grotesque how his little son copies his movements, like a little dog. Our Moldovan family watches the whole process with unease: the mother is more than nervous; the father calmly stoic; the son talks with diplomacy. They did not take us with them for money but because they hoped that, with western Europeans on board, they would more easily cross the border with their smuggled goods.

Normally, we are told later, vehicles carrying EU citizens are simply waved through. The cigarette cartons hidden in the car are found due to the inspection.

The son later says that they are not really smugglers, which seems credible in the face of how nervous his mother appears, but: 'How are we supposed to live?' He says that there are no jobs, or only jobs which pay too little, and the difference in currencies is no longer of use since Romania joined the EU. We can compensate for part of the 
loss by giving them some euros, but we are unable to answer his question. They will sell the legally-imported cigarettes and hope not to have been registered as smugglers.

On our way back a few days later, we experience the whole thing from the other side. Our cabby Radu works in Germany from time to time. He has built Ferris wheels for the Munich Oktoberfest and in the red-light district of Hamburg; he has toured Brandenburg; and he knows the abandoned Ferris wheel located in the ruins of an amusement park in Berlin Treptow, where I live. He uses the money he earns in Germany to buy cars, which he then drives to Galați to build up his taxi company.

Pointing at cigarette dealers, Radu says:

- Illegals from Moldova. They used to sell meat, fish... everything.

Food?

- They haven't got anything else. They're not allowed to bring over food anymore since we joined the EU. It's forbidden.

Cigarettes too, only one carton each.

- Smuggling these is easier.

Radu stops at a fork in the road; he obviously does not know which way to take to the border. Apparently, the taxi entrepreneur has never been to the neighbouring city across the border.

\section{From Galați to the Danube Delta}

Galați on the Danube. Girls are swinging their hips on the promenade: boys are casually shuffling along. The bars and restaurants on the banks of the Danube and on the boats are booming. Like others, we enjoy skewered meat and white wine.

'Could we have the menu again?' we ask, pretending that we want to order some more food - in fact, we have noticed that the prices on the bill are twice what was shown on the menu. We point out this supposed mistake to the waiter.

- The wine is new. It's not on the menu yet.

But the label on the bottle says exactly the same thing as the menu.

- No, the bottle says 'dry', my friend, and the menu says 'sec.' It's a new wine. New wine, new price.

'Sec' and dry is the same thing,' my voice is sounding as if we are already leaving.

- Then I made a mistake. Old price.

When he returns, the money that we see we are now supposed to pay is only onethird more than indicated on the menu. This is the usual fraud here, so we are content.

We cross the Danube on a car ferry, watching the crane parade in the harbour. In the past, when Galați was still called Galatz, quite a lot of Bessarabian goods were shipped from here. Odessa and Galatz were the most important hubs for grain and wine.

On the ferry, we see people on a day trip, anglers and lorries carrying food to the Danube Delta. A sturdy guy who looks like a wrestler, complete with gold necklace 
and a blonde, is standing next to a weather-beaten farmer. How can you not write in clichés when reality complies with the stereotypes spread by the media?

On the other side of the river, we take a minibus, as is customary. The driver is talking on his phone while steering the car with one hand, or else he is flirting with the two girls next to him. The minibus dashes through a spectacular landscape. I look from the driver to the oncoming cars. It is not rare to see crosses by the side of the road showing the picture of someone killed in an accident. Later, in the cemetery in Sulina, I will see quite a lot of new graves of people who have fallen victim to this traffic.

Three pictures of saints are glued to the rear mirror and a crucifix dangles from it. The view reminds me of the cathedral at Chişinau. It was primarily young women who reverently went in there, their hair covered with scarves; crossing themselves, they kissed icons or prayed, and some of them even prostrated themselves. A kitschy Jesus has defeated a kitschy Lenin. Or is Yuri Andrukhovych, the poet, more insightful in calling this region a:

Space of absolute and chronically existential insecurity ... which is why we take it to be extremely religious (as it does itself).

In the villages - it is a Sunday morning - men are sitting over a beer. Open windows show women cooking. A farmer with a donkey cart prevents our tattooed driver from racing on. The worlds of yesterday and today meet.

\section{Sulina}

Sulina - a word that vibrates with a yearning for distant lands, for a beautiful blackhaired woman, for the promise of a world without offices or bureaucracy, for living a life of gentle passion.

In the port of Tulcea, we find the timetable for the transfer to Sulina prominently displayed; a speedboat is supposed to depart in a few minutes. No boat, no passengers on the pier. On the water, ships are rolling next to boats, steamers next to hydrofoils. On the promenade, lined with prefabricated tower blocks, locals and foreigners are bustling about.

The boat leaves from over there, the tall guy says. Nonsense, there's no connection at all today, the short guy replies. Fatso disagrees loudly: the speedboat does not leave today, but the big state-run ferry, which needs six hours for the 70 kilometres, departs in two hours. Another guy intervenes frantically:

Run over there, quickly, behind the boat with the orange sunshade; there it is, the speedboat, it'll take you to Sulina in one and a half hours.

Big strides, my bag under my arm, and the sun is making the sweat ooze out of my pores. Every bit of laughter makes me fear that the last piece of information was a joke made up to see the two Germans run. There is a speedboat floating sluggishly on the water. Will it go to Sulina? It will. In the interior of the Soviet-style hydrofoil, which looks similar to an airplane, I think that only in Albania do passers-by give me so many 
wrong and confusing tips. They do not seem to have bad intentions; apparently, they simply do not know any better, perhaps because everything is changing all the time or because they do not want to remain silent despite not having anything useful to add. The captain explains why his private boat lies so secluded: those areas of the port which are immediately visible are reserved for state-owned ships.

The moorings are cast off, the engine gives a quick, fierce roar, then the boat slowly navigates out of the docks, like an airplane approaching the runway to take off. The boat stops for a moment, the engine grows louder, and then the boat convulses and darts off. The houses and hotel facilities are quickly gone; a scenery of steppe meeting lagoon opens up to our vision. Canals and sea wind, barren waste lands with a few horses, small villages and enchanted huts, a canoe and a barge carrying scrap metal. After a first stop the engine sighs once more, the speedboat lowers itself onto the water and we see a river promenade before our eyes.

Sulina - the city that can only be reached by boat - is easy to describe: boring houses by the dozen, in between some buildings in a bad state of repair which could actually be memorable, as those few which have been refurbished show. Still: this place could be waking up; it is already stretching and many cafés and restaurants are being built along the promenade. The massive curvatures of the church are from a past that was better than the dreary present.

With an unemployment rate of about $40 \%$, many are leaving the city and the Delta. Dogs are left behind; they multiply quickly once they are abandoned. Barking will wake me up next morning. When I look out of the window I see two packs having a scrap as if they were gangs.

Abandoned dogs have been accompanying my trips to eastern Europe for years and this voyage is no different. I saw them in Odessa, louse-ridden and matted, even in the noble city centre; I saw some beg for food in restaurants in Galaţi until they were chased away by a waiter, despite their pleading eyes; and I see them snarling and fighting aggressively in Sulina, over food or a female dog on heat.

Abandoned dogs are a sign of upheaval. Aleksandar Tisma describes in one of his books how Jews in his home town of Novi Sad, herded together in cattle trucks to be deported, are followed by their howling and barking four-legged friends until the transport to the extermination camp has hastened away and is visible only as a smoking dot in the Pannonic lowlands. And Milan Kundera tells of a hunt for the dogs abandoned by those who left Czechoslovakia and the eastern bloc after the Prague Spring was suppressed.

Passing the memorial for the famous conductor George Georgescu (1887-1964), who was born in Sulina, a road winds its way to the coast. In the Christian graveyard, those who have not been lured away by the distant roaring of the sea and the beats of the beach cafés, sirens of a hedonistic society, can find the remains of a European community that existed a long time ago before vanishing in the catastrophes of the $20^{\text {th }}$ century. In the Balkan Wars of 1912, the Danube already lost some of its importance; then two world wars came, followed by the long period of the Cold War; and, in 1989 , the intoxication of freedom that ended in collapse. Now everything that has been shattered has to be reassembled, like a puzzle. But the Sulina branch is only rarely used 
by big freighters now; massive ships that, from a distance, appear to be cutting their way through the plain country.

The older gravestones in the Christian cemetery show Italian names like Giovanni Mattucci, next to others from other European countries. The family grave of the Spanudis from Greece lists dates from three centuries. A big stele has been made for little Valerie Jelinek, who died aged nine in 1897, by the Viennese mason F. D. Hauser. Thomas Bullen, master of the SS Consent, a ship running between Constantinople and Sulina, was killed in an accident on 22 May 1887, aged 39 - a massive slab covers his grave. The dates reveal stories of emigration like the one of Friedrich Dillich, who was born on 19 June 1825 in Schwaan (Mecklenburg, Germany) and who died on 24 January 1886 on the shores of the Black Sea. Taking into consideration what stories from Galicia and Bessarabia a Jewish cemetery could tell, and how a Muslim cemetery would be full of tales from the Ottoman Empire, which has left its mark on this region over centuries - the Azizie mosque in Tulcea still attests to this - entire oceans of imagination open up before my eyes. This was a Europe of diversity. And that means: it can arise anew.

The present: stray dogs are rooting through the rubbish of the screaming yellow beach café with its hammering music of oblivion. A jeep with tinted windows races along on the wet and firm sand. The opening sentences of Heiner Müller's Hamletmaschine (hamlet machine), an endgame of western civilisation, involuntarily cross my mind:

I was Hamlet. I stood on the coast and talked BLAH BLAH to the surf; behind my back the ruins of Europe.

Is it a chimera, or is the pale something on the horizon really the legendary Snake Island, one of the few islands in the Black Sea? White cliff, about half a kilometre in diameter, it is said to rise 40 metres above the sea. During the Cold War, it formally belonged to Romania and, in fact, was a Soviet military base. Today, Ukraine begins there, and tomorrow? The history of Snake Island passing before my mind's eye, I see Greek colonists and Ottoman seafarers, Romanian officers and Soviet captains. According to ancient sources, Achilles's soul came to rest here after the hero fell at Troy. This butcher's belligerent spirit may well seize the island once more when the division of the seabed, which is suspected to hold oil and gas resources underneath, is quarrelled over. Yet, even if this does turn out to be a chimera, the Black Sea will remain in the sights of the big powers, as the bloody war between Russia and Georgia in August 2008 has shown.

The future remains unclear; but one thing is certain: Europe disappears into the Black Sea where the white-crested waves come to a stop on the beach of Sulina. 